\title{
Variation of Stratospheric Aerosol Content Measured by Laser Radar
}

\author{
Part I Seasonal Variation of Aerosol Content and Flux of Sulfur Compounds \\ from Troposphere into Stratosphere
}

\author{
By Yasunobu Iwasaka \\ Water Research Institute, Nagoya University, Nagoya 464, Japan \\ (Manuscript received 25 September 1980, in revised form 3 June 1981)
}

\begin{abstract}
Seasonal variation of stratospheric aerosol content is discussed on the basis of laser radar measurements at Nagoya $\left(35^{\circ} \mathrm{N}, 137^{\circ} \mathrm{E}\right)$ Japan. Analytical results suggest that there were noticeable winter maximum of aerosol content, and this was in good agreement with other investigators' measurements (Hofmann et al., 1975; Bigg, 1975; Hofmann and Rosen, 1977; Reiter et al., 1979). In summer season 1977, and possibly 1976, second maximum of aerosol content was suggested in laser radar measurements at Nagoya. Maximum of stratospheric aerosol content in summer season can be found, though it is small, in the analytical results by Gras and Laby (1979) who suggested the second maximum of aerosol ocntent in summer (southern hemisphere) 1975, and by Reiter et al. (1979) whose results contained small maximum of loading in summer 1977, and 1978. Summarizing various measurements, the winter maximum of aerosol content is always observed on the global scale, and summer second maximum of loading can be sometimes observed.

Present analytical results suggest that the flux of sulfur compounds of $5 \times 10^{7}(\mathrm{~S})$ atoms/ $\mathrm{cm}^{2} / \mathrm{sec}$ from troposphere to stratosphere is necessary to compensate the sedimentational loss of particulate matter if it is assumed that the stratospheric aerosol is composed of sulfuric acid of $75 \%$ in weight.
\end{abstract}

\section{Introduction}

Since Junge discovered the stratospheric aerosol layer over a decade ago (Junge et al., 1961), various scientific researches have been made in order to make clear the nature of stratospheric aerosol particles. The scientific interest on this problem has been stimulated by recent suggestions that the stratospheric aerosol may exsert an important influence on the climate of the earth (Pollack et al., 1976a, 1976b). Consequently there presently exists a fair amount of observational data on the stratospheric aerosols, and these have shown that there exists in the lower stratosphere a world-wide highly structured layer of sulfate containing particles, probably in the form of sulfuric acid, in the 0.1 to 1.0 micron range. But there are considerably less observational informations and agreement concerning such characteristics as seasonal variations, global distribution, sources or sinks of stratospheric aerosols (Hofmann et al., 1975; Reiter et al., 1979).

Laser radar observations of stratospheric aerosols have been made from August 1975 on clean nights at Nagoya $\left(35^{\circ} \mathrm{N}, 137^{\circ} \mathrm{E}\right)$. In this paper, the first of series dealing with results of research program, we should like to present the seasonal change of stratospheric aerosol content using the data during the period from January 1976 to December 1978, relatively quiet time stratosphere, and compare these with previous investigators' measurements (Hofmann et al., 1975; Hirono et al., 1976; Reiter et al., 1979).

The sulfur budget of stratosphere is one of the most essential factor controling the nature of stratospheric aerosol particles, and strongly affects the density variation of stratospheric aerosols. Therefore it is very useful for the research on the stratospheric aerosol behavior to discuss the 
influx of sulfur compounds into stratosphere across the tropopause. The flux of sulfur compounds with gas phase form, such as $\mathrm{SO}_{2}, \mathrm{H}_{2} \mathrm{~S}$, $\mathrm{COS}$, and so on, from troposphere to stratosphere was estimated using analytical results, and estimation shows that the flux of sulfur compounds is about $5 \times 10^{7}$ molecules $/ \mathrm{cm}^{2} / \mathrm{sec}$ under the condition that all of large particles in stratosphere are composed with $75 \%$ sulfuric acid solution and this sulfuric acid is produced through photooxidational reaction of sulfur compounds transported into stratosphere from troposphere (Hofmann et al., 1974; Cadle, 1975; Turco et al., 1979). This estimation is showing good agreement with other investigators' results (Hofmann et al., 1974; Cadle, 1975; Krey, 1970; Turco et al., 1979).

\section{Seasonal change of stratospheric aerosol content}

The main characteristics of laser radar system of Nagoya University are listed up in Table 1. This laser radar can emit the laserpulse at wavelength $=0.6943 \mu \mathrm{m}$ and $1.06 \mu \mathrm{m}$ alternatively at the repetition rate $=0.2 \mathrm{sec}^{-1}$, however, analyzed results presented here are due to only data measured at wavelength $=0.6943 \mu \mathrm{m}$. More detailed information on the characteristics of laser radar system has been described in other paper (Iwasaka et al., 1976), and we will not repeat all of them. The analysis of measurements by laser radar using photoncounting method in receiver depends on the number of photon pulse counted. It is reasonable to assume that the pulses follow a Poisson distribution in time, so that the standard deviation of measurement corresponds to the square of the number of pulses involved, appropriate allowance being made for background noise. In present case a typical night's measurements using ruby laser are based on about one thousand laser shots, therefore the

Table 1

\begin{tabular}{|c|c|}
\hline Laser & $\begin{array}{l}\text { Ruby }(0.6943 \mu \mathrm{m}) \\
\text { YAG }(1.06 \mu \mathrm{m})\end{array}$ \\
\hline Pulse energy & $1 \mathrm{~J} /$ pulse (maximum) \\
\hline Pulse duration & $20 \mathrm{nsec}$ \\
\hline Repetition rate of pulse & $0.2 \mathrm{sec}^{-1}$ \\
\hline Photomultiplier & $40 \mathrm{~cm} \phi$ \\
\hline Receiver telescope & R649(Ruby), R139(YAG) \\
\hline Filter band width & $10 \AA$ (Ruby), $50 \AA(Y A G)$ \\
\hline Rotating shutter & $24,000 \mathrm{rpm}$ \\
\hline
\end{tabular}

* Present analysis does not include the measurements at wavelength $=1.06 \mu \mathrm{m}$, statistical error becomes smaller than few per cent at $20 \mathrm{~km}$ level.

In order to derive aerosol scattering profiles the expected Rayleigh scattering from the molecular atmosphere must be subtracted from the experimental profiles. For height up to $35 \mathrm{~km}$ we have calculated the Rayleigh scattering on the basis of model atmosphere due to U.S. Standard Atmosphere Supplement (1966). Comparison between the lidar profiles and the calculated molecular atmosphere was made by visible curve fitting (e.g., Russell et al., 1976). It was sometimes possible to fit the curve both above and below the height at which any aerosol scattering present was observed, but in case where aerosol scattering was present at the lowest data point, the fitting was done only at height of $30 \mathrm{~km}$ or above.

The scattering ratio due to particulate matter, $R(Z)$ is defined by following equation,

$$
R(Z)=\left[B_{r}(Z)+B_{m}(Z)\right] / B_{r}(Z)
$$

where $B_{r}(Z)$ and $B_{m}(Z)$ are backscattering coefficient of atmospheric molecules and of aerosol particles at altitude, $Z$ respectively. And backscattering coefficient of aerosol particles is estimated using $R(Z)$ by

$$
B_{m}(Z)=[R(Z)-1] b_{r} n(Z)
$$

where $n(Z)$ is number density of air molecules at altitude $Z$, and $b_{r}$ is backscattering crosssection of molecules at wavelength $=0.6943 \mu \mathrm{m}$. Previously some investigators discussed on the procedure to determine the scattering ratio or backscattering coefficient of stratospheric aerosols and related problems with this procedure (Sanford, 1976; Russell et al., 1976; Itabe et al., 1977), then this is not described here.

Laser radar measurements of stratospheric aerosols have been carried out at Nagoya approximately three times a month since August 1975, and this frequency of measurements has proven satisfactory for studying the variation of aerosol content with the time scale of season. The data measured during the period from January 1976 to December 1978 were used for analysis in this paper. This data shows the effect of Mt. Fuego eruption on the stratospheric aerosol content variation, but this is not so serious problem to discuss the seasonal change of aerosol content since we can easily distinguish seasonal component from the over all trend of backscattering coefficient measured in this period (see Figs. 1, 2, 3, and 4).

The running mean value of three months on 


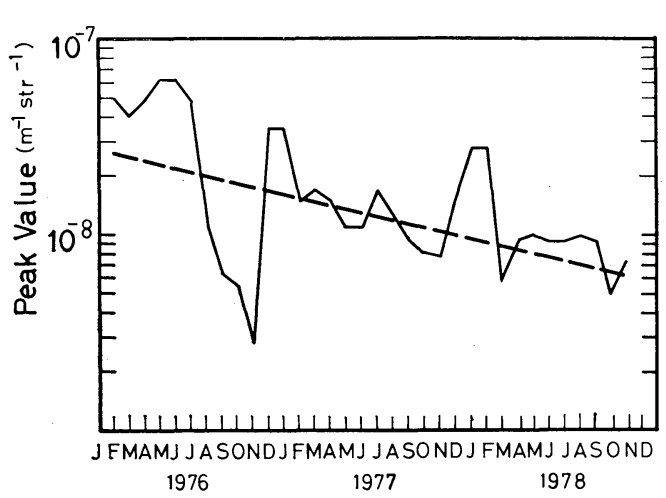

Fig. 1. Backscattering coefficient at the peak of stratospheric aerosol layer. The solid curve is three-monthly averaged value and dotted curve is the decay curve of backscattering coefficient gained by least squared method.

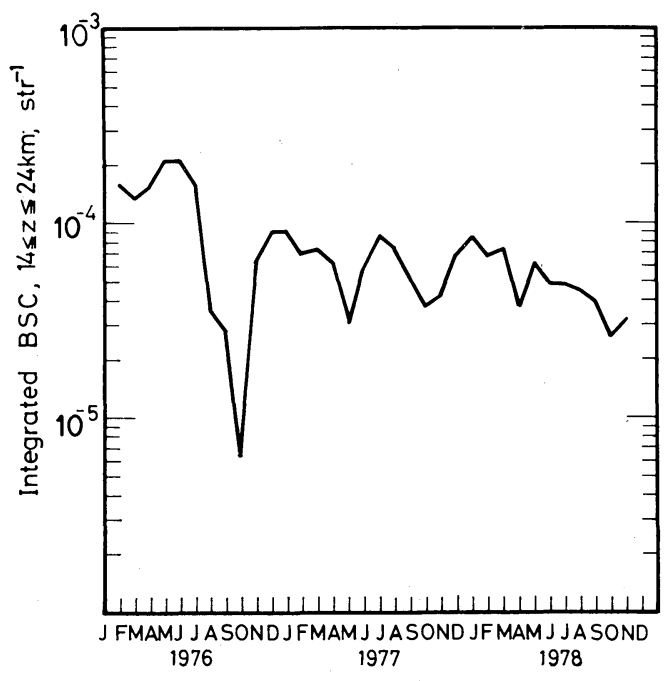

Fig. 2. Vertically integrated value of backscattering coefficient in the range, $14 \mathrm{~km}$ $24 \mathrm{~km}$. The curve is three-monthly average.

the backscattering coefficient at particle layer peak is shown in Fig. 1. Noticeable seasonal component on the aerosol content variation in the curve of Fig. 1 dominates the temporal variation at Nagoya $\left(35^{\circ} \mathrm{N}, 137^{\circ} \mathrm{E}\right)$ and appears to be superimposed on a long term variation which must be connected with the decay processes of aerosol content which increased suddenly due to volcanic material loading into stratosphere by the eruption of Mt. Fuego. The long term decay curve is approximated using dotted curve, and this decay curve suggests that the decay life

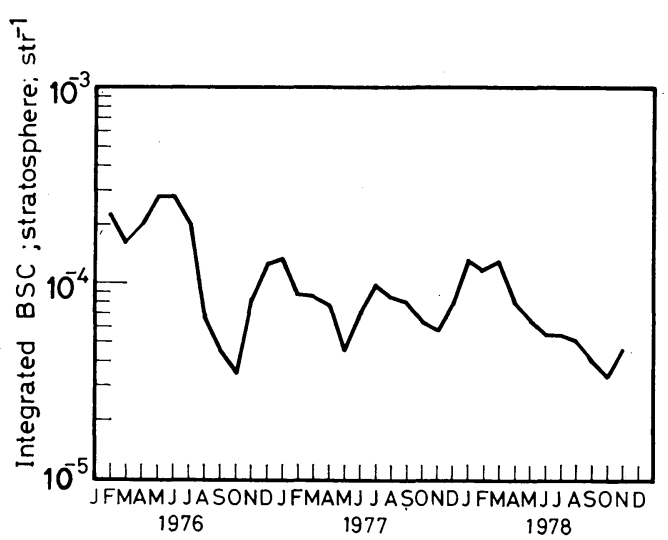

Fig. 3. Vertically integrated value of backscattering coefficient in all over the stratosphere (above tropopause height). The curve is three-monthly average.

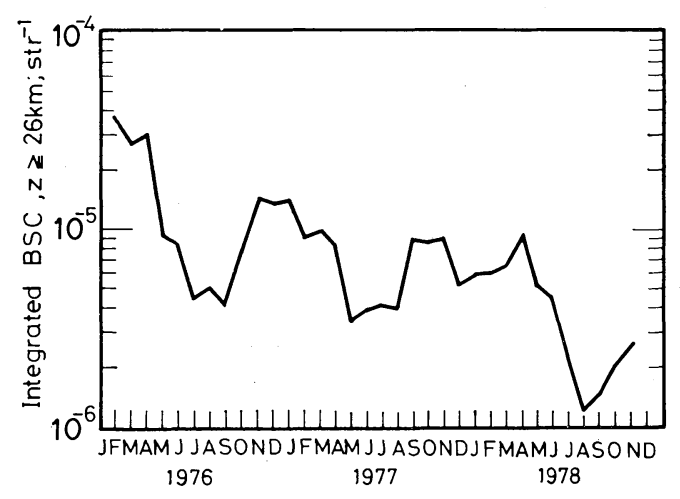

Fig. 4. Vertically integrated value of backscattering coefficient above the height of $26 \mathrm{~km}$. The curve is three-monthly average.

time of aerosol content is about 2 years. The detailed discussion on the decay of stratospheric aerosol content after the volcanic eruption will be discussed in another paper of this research program (Iwasaka, 1981). The maximum of peak values is found out in winter season '76, '77, and '78 as was already pointed out in the results of balloon soundings by the University of Wyoming's Atmospheric Physics Group during the observation 1972 and 1973 (1975). On the whole maximum in winter season is evidently found out during all observational period and summer maximum seems to decrease year by year. The winter maximum in temporal variation of stratospheric aerosol content can be seen also in integrated backscattering coefficient in the region from $14 \mathrm{~km}$ to $24 \mathrm{~km}$ (Fig. 2), in integrated value in over all stratosphere (Fig. 3), 
and in integrated value above $26 \mathrm{~km}$ (Fig. 4). The summer maximum has not been claimed in previous investigations, but apparently found out in measurement at Garmisch-Partenkirchen $\left(47^{\circ} \mathrm{N}, 11^{\circ} \mathrm{E}\right.$ ) from Oct. '76 to June '78 (Reiter et al., 1979). The data due to balloon borne particle counter does not show so large peak as winter maximum in summer season, but apparently small secondary peaks are found in late spring or early summer ' $72,{ }^{7} 73$, and ' 75 in the time series of measured total stratospheric aerosol in a $1 \mathrm{~cm}^{-2}$ column (aerosol radius $>0.15 \mu \mathrm{m}$ ) (Hofmann et al., 1975; Hofmann and Rosen, 1977).

\section{Discussion and conclusion}

The winter maximum of stratospheric aerosol content indicated by laser radar measurements at Nagoya $\left(35^{\circ} \mathrm{N}, 137^{\circ} \mathrm{E}\right)$ is one of the typical tendency found out in the measurement at northern mid latitude during no-disturbed stratosphere. Previously Hofmann et al. reported the existence of winter maximum of stratospheric aerosol content on the basis of the measurements using balloon borne optical dust counter at Laramie $\left(41^{\circ} \mathrm{N}, 105^{\circ} \mathrm{W}\right)(1975)$. The agreement between laser radar and balloon data revealed in this manner is quite striking. According to Bigg, very similar results have been found in the measurements of number concentration of stratospheric aerosols at Mildura, Australia $\left(34^{\circ} \mathrm{S}\right.$, $142^{\circ} \mathrm{E}$ ) during the observational period from May 1969 to April 1974 (1976). In the measurements at Sao Jose dos Campos $\left(23^{\circ} \mathrm{S}, 47^{\circ} \mathrm{E}\right)$ the noticeable seasonal component cannot be found during quiet stratospheric period (Clemesha and Simonich, 1978). In laser radar measurements at Garmish-Partenkirchen $\left(47.5^{\circ} \mathrm{N}\right)$ and Menlo Park $\left(35^{\circ} \mathrm{N}\right)$, noticeable winter maxima of aerosol content were seen (Russell et al., 1976; Reiter et al., 1979). Minimum in autumn in the measurements by laser radar is noticeable at Nagoya $\left(35^{\circ} \mathrm{N}\right)$, and found out also in the total stratospheric aerosol content measured by Hofmann and Rosen (1975). The summer maximum is very noticeable in the measurement at Nagoya, and not in other laser radar measurements. However, small summer maximum is recognized in measurements at Garmis Garmish-Partenkirchen (laser radar measurement), and at Laramie, Wyoming (optical particle counter method). This summer maximum is rather unsteady, and decrease gradually year by year at Nagoya. As is discussed by Hofmann et al, (1975), and
Hofmann and Rosen (1977), the mechanism which produces above mentioned seasonal variation of aerosol content is possibly due to the variation of tropopause height, which provides an effective cleaning process of material in stratosphere. In addition to this, the air motions of global scale such as jet stream, various wave, and so on must affect on aerosol transportation, and causes difference among the measurements at various location.

The main processes which are controlling the behavior of stratospheric aerosol layer are eddy diffusion of aerosol, sedimentation, coagulation between particles, condensation of sulfuric acid vapor on to particle surface, and production of sulfuric acid vapor through photo-oxidation processes of $\mathrm{COS}, \mathrm{SO}_{2}, \mathrm{H}_{2} \mathrm{~S}$ and so on transported into from troposphere by eddy diffusion (e.g., Junge et al., 1961; Hamill et al., 1978; Toon et al., 1979).

The rate of stratospheric aerosol number density change is described as following form

$$
\frac{\partial n}{\partial t}=\operatorname{div}\left(F_{1}+F_{2}\right)+P_{1}+L_{1}+P_{2}+L_{2}+P_{3}
$$

where $n$ is aerosol differential number density in the radius range $R \sim R+d R, F_{1}$ eddy diffusion flux due to sedimentation, $P_{1}$ production rate due to condensation or evaporation of $\mathrm{H}_{2} \mathrm{SO}_{4}$ vapor, $L_{1}$ loss rate due to condensation or evaporation of $\mathrm{H}_{2} \mathrm{SO}_{4}$ vapor, $P_{2}$ production rate due to coagulation, $L_{2}$ loss due to coagulation, $P_{3}$ production rate due to homogeneous nucleation. The column density of stratospheric aerosol particles in unit of $\mathrm{g} / \mathrm{cm}^{2}$ is given by

$$
N=\int_{Z_{2}}^{Z_{1}} \int_{R_{2}}^{R_{1}} \frac{4}{3} \pi R^{3} \rho n(R) d R d Z
$$

where $\rho$ is density of particulate matter $\left(\mathrm{g} / \mathrm{cm}^{3}\right)$, $Z_{1}$ and $Z_{2}$ layer top and bottom respectively, $R_{1}$ and $R_{2}$ aerosol size limit, the number density $S$ of aerosol is given by

$$
S=\int n(R) d R
$$

The terms controlled by coagulation are cancelled out when following integration is done

$$
\int_{Z_{2}}^{Z_{1}} \int_{R_{2}}^{R_{1}}\left(P_{2}+L_{2}\right) d R d Z=0
$$

The contribution of homogeneous nucleation is possibly neglected (Toon et al., 1979). The following integration (7) means the rate of particulate matter change (here $75 \%$ sulfuric 
acid solution is assumed) through condensation of $\mathrm{H}_{2} \mathrm{SO}_{4}$ vapor onto aerosol surface, and is considered to be equal to rate of $\mathrm{H}_{2} \mathrm{SO}_{4}$ gas change in column,

$$
P_{\mathrm{H}_{2} \mathrm{SO}_{4}}=\int_{Z_{2}}^{Z_{1}} \int_{R_{2}}^{R_{1}}\left(P_{1}+L_{1}\right) \frac{4}{3} \pi R^{3} \kappa d R d Z
$$

where $\kappa$ is constant determined by the chemical composition assumed here. The vertical integration of divergence term in equation (3) is rewritten as following form (only vertical fluxes are assumed)

$$
\begin{aligned}
& \int_{Z_{2}}^{Z_{1}} \operatorname{div}\left(F_{1}+F_{2}\right) d Z \\
& \quad=\left[F_{1}+F_{2}\right]_{\text {top }}-\left[F_{1}+F_{2}\right]_{\text {bottom }}
\end{aligned}
$$

where "top" and "bottom" mean the top of stratospheric aerosol layer and bottom of layer respectively. The flux of particulate matter is defined by

$$
\phi_{i}=\int_{R_{2}}^{R_{1}} \frac{4}{3} \pi R^{3} \rho F_{i} d R, \quad i=1 \text { or } 2
$$

The rate of particulate matter change in column is given by

$$
\frac{\partial N}{\partial t}=\left(\phi_{1}+\phi_{2}\right)_{\text {top }}-\left(\phi_{1}+\phi_{2}\right)_{\text {bottom }}+P_{\mathrm{H}_{2} \mathrm{SO}_{4}}
$$

As is seen in equation (10), the budget of particulate matter in the stratosphere is controlled by the production due to condensation of $\mathrm{H}_{2} \mathrm{SO}_{4}$ vapor onto pre-existing particles and loss due to sedimentation or diffusion of particles. Considering that sulfuric acid contained in particles is produced through photo-oxidational reaction of sulfur compounds transported into stratosphere across the tropopause, and that most of $\mathrm{H}_{2} \mathrm{SO}_{4}$ is contained in aerosols as the form of sulfuric acid solution, the influx of sulfur compounds is necessary to compensate the production rate of $\mathrm{H}_{2} \mathrm{SO}_{4} 75 \%$ solution. Schematically sulfur compounds budget in stratosphere is illustrated in Fig. 5.

Considering that the stratospheric aerosol is essentially large particle produced through condensation of $\mathrm{H}_{2} \mathrm{SO}_{4}$ vapor and coagulation of particles, as is pointed out by Hamill et al. (1978), and Toon et al., (1979), it is assumed that the increase of vertically integrated backscattering coefficient in winter season is mainly due to gas-to-particle conversion process such as condensation of sulfuric acid vapor on aerosol surface. The ratio, $G_{p}$, of particle backscattering

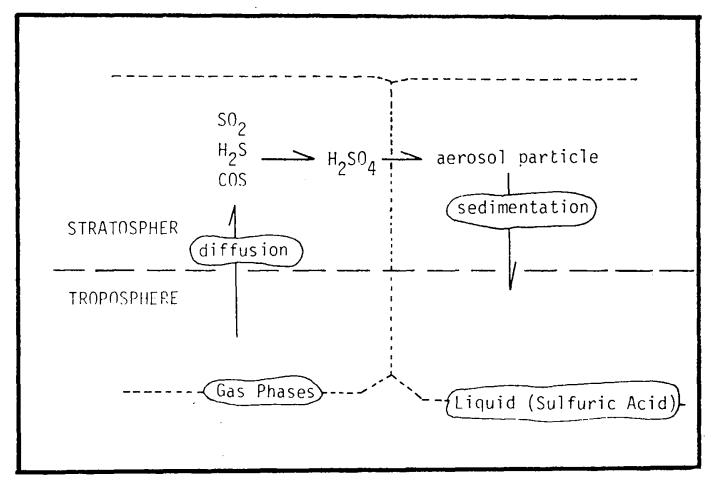

Fig. 5. Schematic illustration on the cycle of sulfur compounds. Various gas phase sulfur compounds are converted to liquid phase matter through so-called "gas to particle conversion" on stratosphere. All aerosol particles are assumed to be composed with $75 \%$ sulfuric acid solution according to many investigations (e.g., Toon et al. 1979).

coefficient to particle number density measured by balloon borne particle counter is already discussed (Russell et al., 1975; Remsberg and Northam, 1975). If we use the value $G_{p}=$ $4.7 \times 10^{-11} \mathrm{~cm}^{2} \operatorname{str}^{-1}(\lambda=0.6943 \AA)$, as is presented by Russell et al. (1975) and Remsberg and Northam (1975), and assumption that all particles are composed with sulfuric acid solution of $75 \%$

\begin{tabular}{|c|c|c|}
\hline $\begin{array}{l}\text { Flux of } \\
\text { sulfur }\end{array}$ & Constituent & Comment \\
\hline $6 \times 10^{6}$ & $\cos$ & $\begin{array}{l}\text { Model calculation } \\
\text { (Crutzen, 1976) }\end{array}$ \\
\hline $5 \times 10^{6}$ & $\mathrm{SO}_{2}$ & $\begin{array}{l}\text { Analysis of residence time } \\
\text { (June, 1974) }\end{array}$ \\
\hline $2 \times 10^{7}$ & $\mathrm{SO}_{2}$ & $\begin{array}{l}\text { Seasonal variation of aer- } \\
\text { osol content (Hofmann, } \\
\text { et al., 1974) }\end{array}$ \\
\hline $9 \times 10^{6}$ & $\mathrm{SO}_{2}$ & $\begin{array}{l}\text { Model calculation (Laz- } \\
\text { rus and Gundred, 1974) }\end{array}$ \\
\hline $1.8 \times 10^{7}$ & $\mathrm{SO}_{2}$ & $\begin{array}{l}\text { Analysis of volcanic ac- } \\
\text { tivity observation (Cadle, } \\
\text { 1975) }\end{array}$ \\
\hline $3 \times 10^{8}$ & $\mathrm{SO}_{2}$ & $\begin{array}{l}\text { Model calculation (Harri- } \\
\text { son and Larson, 1974) }\end{array}$ \\
\hline $5.4 \times 10^{7}$ & $\begin{array}{l}\mathrm{SO}_{2}, \mathrm{COS}, \mathrm{H}_{2} \mathrm{~S} \\
\text { (not identified) }\end{array}$ & $\begin{array}{l}\text { Analysis of seasonal vari- } \\
\text { ation of aerosol content } \\
\text { (present research) }\end{array}$ \\
\hline
\end{tabular}
(weight) and density of particle $\rho=1.6 \mathrm{~g} / \mathrm{cm}^{3}$, then the increase of mass of particulate matter, $\Delta M$ is given by

Table 2

* Unit of flux of sulfur: (atoms $/ \mathrm{cm}^{2} / \mathrm{sec}$ ) 


$$
\Delta M=\rho \iint\left(B_{m}(Z) / G_{p}\right)\left(4 / 3 \pi \bar{R}^{3}\right) d D d t
$$

where $\Delta Z$ means the vertical range from layer bottom to layer top, $\Delta t$ means time span of winter season, and $R$ is average radius of stratospheric aerosol $(0.25 \mu \mathrm{m})$. On the basis of results in Fig. 3, $\Delta M$ in winter season is about $1.8 \times$ $10^{-7} \mathrm{~g} / \mathrm{cm}^{2}$ (column). This indicates that average production rate of $\mathrm{H}_{2} \mathrm{SO}_{4}$ solution in winter season is $8.5 \times 10^{15} \mathrm{~g} / \mathrm{cm}^{2} / \mathrm{sec}$ for the time scale, $1.5 \times 10^{7} \mathrm{sec}$ (about 6 months), and corresponding to flux of sulfur atoms into stratosphere $=5.4 \times$ $10^{7}$ atoms $(\mathrm{S}) / \mathrm{cm}^{2} / \mathrm{sec}$. In table 2 , influx of sulfur compounds estimated here is compared with other investigators' results. Present value has good agreement with other investigations, though the estimation was done very roughly.

\section{Acknowledgements}

The author would like to thank Rof. A. Ono, Nagoya University for useful discussion. He also thanks Mr. A. Mita, Mr. K. Nagaya, Nagoya University, and Mr. M. Wada, National Institute of Polar Research for helpful assistance of laser radar observation.

\section{References}

Bigg, E. K., 1975: Stratospheric particles. J. Atmos. Sci., 32, 910-917.

Cadle, R. D., 1975: Volcanic emission of halides and sulfur compounds to the troposphere and stratosphere. J. Geophys. Res., 80, 1650-1652.

Clemensa, B. R., and D. M. Simonich, 1978: Stratospheric dust measurements 1970-1977. J. Geophys. Res., 83, 2403-2408.

Crutzen, J. J., 1976: The possible importance of CSO for the sulfate layer of the stratosphere. Geophys. Res. Letters, 3, 73-76.

Gras, J. L., and J. E. Laby, 1976: Southern hemisphere stratospheric aerosol measurements 2 . Time variations and the 1974-1975 aerosol events. $J$. Geophys. Res., 84, 303-307.

Hamill, P., O. B. Toon, and C. S. Kiang, 1977: Microphysical processes affecting stratospheric aerosol particles. J. Atmos. Sci., 34, 1104-1119.

Harrison, H., and T. Larson, 1974: The oxidation of $\mathrm{SO}_{2}$ in the stratosphere. J. Geophys. Res., 79, 3095-3097.

Hirono, M., M. Fujiwara, T. Itabe, and C. Nagasawa, 1977: On the long term variations of stratospheric aerosol content after the eruption of Fuego volcano observed by lidar. J. Geomag. Geoelectr., 29, 541-556.

Hofmann, D. J., J. M. Rosen, and T. J. Pepin, 1974: Global measurements of the time variations and morophology of the stratospheric aerosol, Proc. Third Conf. on CIAP, ed. by A. J. Broderick, and T. M. Hard, 284-297.

- —, and R. G. Pinnick, 1975: Stratospheric aerosol measurements I: Time variations at northern mid latitude, J. Atmos. Sci., 32, 1446-1456.

, and - 1977: Balloon observations of the time deevlopment of the stratospheric aerosol event of 1974-1975. J. Geophys. Res., 82, 1435-1440.

Itabe, T., M. Fujiwara, and M. Hirono, 1977: Temporal variation of the stratospheric aerosol layer after the Fuego eruption observed by lidar in Fukuoka. J. Met. Soc., Japan, 55, 606-612.

Iwasaka, Y., A. Mita, and K. Isono, 1976: Stratospheric aerosol measurement by two-color lidar. Rep. Ionos. Space Res., Japan, 30, 16-20.

Iwasaka, Y., 1981: Variation of stratospheric aerosol content measured by lidar; II, Long term trend of post Fuego eruption. (submitted to J. Met. Soc., Japan.)

Junge, C. E., C.W. Chabnon, and J. E. Manson, 1961: Stratospheric aerosols, J. Met., 18, 81-108. , 1974: Important problems of global pollution. Proc. Intern. Conf. Structure, Composition, and General Circulation of the Upper and Lower Atmospheres and Possible and Anthropogenic Perturbations. Melbourne, Australia.

Lazrus, A. L., and B. W. Gandrud, 1974: Stratospheric sulfate aerosol. J. Geophy. Res. 79, 34243431.

Pollack, J. B., O. B. Toon, C. Sagan, A. Summers, B. Baldwin, and W. Van Camp, 1976a: Volcanic explosion and climatic change: a theoretical assessment. J. Geophys. Res. 81, 1071-1083.

Camp, and B. Baldwin, 1976b: Estimates of the climatic impact of aerosols produced by space shuttles, SST's and other high flying aircraft. $J$. Appl. Met., 15, 247-258.

Reiter, R., H. Jager, W. Carnuth, and W. Funk, 1979: The stratospheric aerosol layer observed by lidar since October 1976. A contribution to the problem of hemispheric climate. Arch. Met. Geoph. Biokl., B27, 121-149.

Remsberg, E. E., and G. B. Northam, 1975: A comparison of dust sonde and lidar measurements of stratospheric aerosols, Proc. Fourth Conf. of $C I A P$, ed. by T. M. Hard, and A. J. Broderick, 509-518.

Russell, P. B., W. Viezee, R. D. Hake, Jr., and R. T. Collis, 1976: Lidar observations of the stratospheric aerosol. California, October 1972-March 1974. Quart. J. Roy. Met. Soc., 102, 619-639.

$\longrightarrow,-,-1975:$ Lidar observations of stratospheric aerosol: Summary of results and calibration error assessment, 
Proc. Fourth Conf. on CIAP, ed. by T. M. Hard, and A. J. Brederick, 497-508.

Sanford, M. C. W., 1967: Optical radar performance in atmospheric scattering. J. Atmos. Terr. Phys., 29, 1651-1656.

Toon, O. B., R. P. Turco, P. Hamill, C.S. Kiang, and R. C. Whitten, 1979: A one-dimensional model describing aerosol formation and evolution in stratosphere, II. Sensitivity studies and comparison with observations, J. Atmos. Sci., 36, 718-736.

Turco, R. P., P. Hamill, O. B. Toon, R. C. Whitten, and C.S. Kiang, 1979: A one-dimensional model describing aerosol formation and evolution in the stratosphere: I. Physical processes and mathematical analog. J. Atmos. Sci., 36, 699-717.

\title{
レーザレーダによって観測された成層圈エアロゾルの濃度変化
}

\section{第 I 部＼cjkstart季節変化と，対流圈から成層圈へのイオウ化合物の流束}

\author{
岩坂 泰信 \\ 名古屋大学水圈科学研究所
}

名古屋に和けるレーザレーダ観測の結果をもとに, 成層圏エアロゾル濃度の季節変化について議論した。結果 は, 顕著な冬季の極大が欢られ, 他の研究者の結果と同様なものである (Hofmann et al., 1975; Hofmann and Rosen, 1977; Bigg, 1975; Reiter et al., 1979)。名古屋での結果は, 1977年さらには1976年の夏季にも第の極大 が見られる。小さな夏季の極大は, 他の研究者の結果にも見出されて扣り, 1975年の夏の極大は Gras and Laby (1979) の結果に, 又 1978 年及び1977年の夏の極大は, Reiter 等の観測に見られる。種々の結果をまとめてみる 期と，冬の極大は定常的に地球規模で観測され，小さい冬の極大が時々見られる。

もし成層圈エアロゾルが，75\%の硫酸液滴からなっていると考えるなら，粒子状物質が沈降によって失われる 量とつりあうためには，イオウ化合物の対流圈から成層圏への flux は, $5 \times 10^{7}$ (s) atoms $/ \mathrm{cm}^{2} / \mathrm{sec}$ である。 